\title{
Atrial natriuretic peptide, aldosterone, and plasma renin activity in peripartum heart failure
}

\author{
C O Adesanya, F I Anjorin, I A Sada, E H O Parry, G A Sagnella, G A MacGregor
}

\author{
Department of \\ Medicine, Ahmadu \\ Bello University \\ Hospital, Zaria, \\ Nigeria \\ CO Adesanya \\ F I Anjorin \\ I A Sada \\ Wellcome Tropical \\ Institute, London \\ E H O Parry \\ Blood Pressure Unit, \\ Department of \\ Medicine, St George's \\ Hospital Medical \\ School, London \\ G A Sagnella \\ G A MacGregor \\ Correspondence to \\ Professor CO Adesanya, \\ Ahmadu Bello University \\ Hospital, \\ Zaria, Nigeria. \\ Accepted for publication \\ 4 December 1990
}

\begin{abstract}
Plasma concentrations of atrial natriuretic peptide and aldosterone and plasma renin activity were measured in patients with peripartum heart failure and in age matched healthy women post partum. Both groups had carried out traditional postpartum practices of salt consumption and body heating. Plasma concentrations (mean (SEM)) of atrial natriuretic peptide were significantly higher in the seven patients with peripartum heart failure $(146.9(24.3) \mathrm{pg} /$ ml) than in the seven controls $(4 \cdot 4(0.8)$ $\mathrm{pg} / \mathrm{ml})$. Both plasma aldosterone and plasma renin activity were suppressed in the patients with peripartum heart failure. After treatment for the heart failure plasma atrial natriuretic peptide fell considerably and there were associated increases in plasma aldosterone and plasma renin activity.

The high plasma concentrations of atrial natriuretic peptide may have been a compensatory respense to salt and water retention as well as to the heart failure. These high concentrations could also, in part, have suppressed the release of aldosterone and renin in an attempt to correct for volume overload.
\end{abstract}

Women in and around Zaria in northern Nigeria who develop peripartum heart failure have customarily eaten large quantities of lake salt (Kanwa) and water in the early postpartum period. ${ }^{1}$ They are also likely to have performed the ritual of body heating. Both of these practices can increase blood volume and have been associated with high output cardiac failure. ${ }^{2}$ These women have no evidence of underlying cardiac or renal disease. Besides the volume expansion, the pressure load of postpartum hypertension may also contribute to the cardiac damage in susceptible individuals. So far the role of the kidney's ability in handling the salt load in peripartum heart failure has not been determined. Several factors are important in the control of renal sodium excretion, in particular the reninangiotensin-aldosterone system and the newly discovered atrial natriuretic peptides. Little is known about these hormonal determinants in peripartum heart failure. In the present study we measured circulating concentrations of atrial natriuretic peptide, and aldosterone and renin activity in women before and after treatment for peripartum heart failure.
Patients and methods

We studied seven patients (mean age 28; range 21-30 years) with peripartum heart failure. All the patients and controls had carried out the postpartum rituals of body heating. In addition to the estimated daily salt intake of approximately $10 \mathrm{~g}$, all but one patient (case 6) had ingested large quantities of Kanwa, a lake salt. The traditional dose of Kanwa is approximately $30 \mathrm{~g} /$ day. This has been estimated to contain $450 \mathrm{mmol}$ of sodium. Kanwa is taken in pap with large amounts of water daily for $\mathbf{4 0}$ days or more. The patients were admitted to hospital and their symptoms and signs were recorded. Particular attention was paid to the examination of the cardiovascular system. Blood pressure, pulse, jugular venous pressure, and the precordium were carefully examined. The measurement of jugular venous pressure was used as an indication of central venous pressure. It was measured with the patients semi-sitting at an angle of 30 or $45^{\circ}$ with the head turned to the left. The patients were weighed and before treatment routine investigations (chest $x$ ray, electrocardiogram, full blood count, urea and electrolytes, serum proteins, urine analysis and spot urine sodium) were performed. Treatment was started before a $24 \mathrm{~h}$ urine sample was collected for the measurement of sodium. Atrial natriuretic peptide ( $\alpha$ ANP), aldosterone, and plasma renin activity were measured before treatment and up to seven days after treatment with digoxin, frusemide, and salt restriction. Except for chest $x$ rays, the controls also had similar routine investigations and hormone assays.

\section{BLOOD COLLECTION}

Venous blood was collected at noon with the woman in the semi-sitting (cardiac) position. The samples were collected into EDTA tubes to measure plasma renin activity; in heparin tubes for aldosterone, and into EDTA tubes plus $15 \mu \mathrm{l}$ of trasylol solution $(5000 \mathrm{KIU} / \mathrm{ml}$; Bayer, Aprotinin) to measure atrial natriuretic peptide. Similar methods were used to analyse blood samples collected after treatment. The blood samples were immediately centrifuged at $4^{\circ} \mathrm{C}$ and the plasma was stored in clear plastic tubes at $-20^{\circ} \mathrm{C}$. Plasma samples for renin were preserved in EDTA tubes; those for aldosterone and atrial natriuretic peptide were placed in clear plastic tubes. All samples for hormone measurements were stored at $-20^{\circ} \mathrm{C}$ until they were transported, in the frozen state, to London, where plasma atrial natriuretic peptide, aldosterone, and plasma 
renin activity were measured by radioimmunoassay as described elsewhere. ${ }^{3}$

We used paired or unpaired tests as appropriate for group comparisons. Nonparametric tests were used for urinary sodium and plasma hormone measurements because of considerable differences in sample variances and also because of uncertainty about the form of the distribution for these measurements in the patient group. A p value of $<0.05$ was regarded as statistically significant. Results are given as means (SEM).

\section{Results}

All controls had normal physical findings, were normotensive, and had normal cardiograms. All the patients with peripartum heart failure were in gross congestive heart failure (class IV, New York Heart Association criteria). Tables 1 and 2 summarise the clinical data. The patient group had slightly raised blood pressure on admission (table 1). This was transient and not consistent with systemic hypertension. Fundoscopic findings in these patients were also normal. In both the patients and controls a full blood count, urine analysis, urea, electrolytes, and serum proteins were all within the

Table 1 Clinical data (mean (SEM)) on patients with peripartum heart failure and on healthy puerperal women

\begin{tabular}{lcrl}
\hline & $\begin{array}{l}\text { Controls } \\
(n=7)\end{array}$ & $\begin{array}{l}\text { Heart } \\
\text { failure } \\
(n=7)\end{array}$ & p value \\
Variable & $28(1.5)$ & $28(1.5)$ & NS \\
\hline Age (yr) & $3(0.7)$ & $3(0.7)$ & NS \\
$\begin{array}{l}\text { Last delivery (mnth) } \\
\text { Parity }\end{array}$ & $5(0.4)$ & $6(0.7)$ & NS \\
$\begin{array}{l}\text { Duration of symptoms } \\
\text { (mnth) }\end{array}$ & - & $1.4(0.4)$ & - \\
$\begin{array}{l}\text { Systolic blood pressure } \\
\text { (mm Hg) }\end{array}$ & $120(3.8)$ & $140(9.8)$ & NS \\
$\begin{array}{l}\text { Diastolic blood pressure } \\
\text { (mm Hg) }\end{array}$ & $86(3.0)$ & $107(4.5)$ & $<0.01$ \\
Heart rate (beats/min) & $85(4 \cdot 1)$ & $108(4.5)$ & $<0.01$ \\
JVP (cm) & - & $7(0.7)$ & - \\
\hline
\end{tabular}

JVP, jugular venous pressure.

Table 2 Laboratory data (mean (SEM)) on controls and women with peripartum heart failure

\begin{tabular}{|c|c|c|c|}
\hline & $\begin{array}{l}\text { Controls } \\
(n=7)\end{array}$ & $\begin{array}{l}\text { Heart } \\
\text { failure } \\
(n=7)\end{array}$ & pvalue \\
\hline $\begin{array}{l}\text { Packed cell volume }(\%) \\
\text { Spot urinary sodium}\end{array}$ & $40(1.9)$ & $38(1.9)$ & NS \\
\hline $\begin{array}{l}\text { (mmol/1) } \\
\text { Serum albumin (g/l) } \\
\text { Cardiothoracic ratio }\end{array}$ & $\begin{array}{l}188(18 \cdot 5) \\
43(1.9) \\
-\end{array}$ & $\begin{array}{l}89(1.5) \\
37(1.5) \\
0.64(0.03)\end{array}$ & $\begin{array}{l}<0.05 \\
\text { NS } \\
-\end{array}$ \\
\hline
\end{tabular}

*Treatment started before the 24 hour urine collection was completed.

Table 3 Plasma atrial natriuretic peptide, aldosterone, and plasma renin activity in healthy puerperal women and in patients with peripartum heart failure (before treatment)

\begin{tabular}{lccl}
\hline & $\begin{array}{l}\text { Controls } \\
(n=7)\end{array}$ & $\begin{array}{l}\text { Heart } \\
\text { failure } \\
(n=7)\end{array}$ & p value* \\
\hline $\begin{array}{l}\text { Plasma ANP (pg/ml) } \\
\text { Plasma aldosterone }\end{array}$ & $4.4(0.8)$ & $146.9(24.3)$ & $<0.01$ \\
$\begin{array}{l}\text { (pmol/l) } \\
\text { PRA (ng/ml/h) }\end{array}$ & $\begin{array}{c}139.0(15.1) \\
3.4(2.4)\end{array}$ & $\begin{array}{c}85.6(13.7) \\
0.43(0.24)\end{array}$ & $\begin{array}{l}<0.05 \\
\text { NS }\end{array}$ \\
\hline
\end{tabular}

^Non-parametric unpaired tests.

ANP, atrial natriuretic peptide; PRA, plasma renin activity. normal range. The patients had cardiomegaly on chest $x$ ray and the electrocardiogram showed sinus tachycardia and non-specific ST changes. The patients responded promptly to treatment with an average weight loss of 12 $(0 \cdot 8) \mathrm{kg}$ (admission weight $58(1 \cdot 7)$, discharge weight $46(1 \cdot 1) \mathrm{kg}$ ) and the disappearance of peripheral oedema. Dyspnoea and other symptoms subsided as the jugular venous pressure fell to normal, implying a reduction in the extracellular fluid volume and in pulmonary venous congestion.

Table 3 shows the plasma concentrations of atrial natriuretic peptide, aldosterone, and renin before treatment in the patients with peripartum cardiac failure and the controls. Plasma concentrations of atrial natriuretic peptide were significantly higher (146.9 (24.3) $\mathrm{pg} / \mathrm{ml}$ ) in the women with peripartum heart failure than in the controls $(4.4(0.8) \mathrm{pg} / \mathrm{ml})$. After treatment for the heart failure plasma atrial natriuretic peptide fell considerably (figure). Before treatment plasma aldosterone in the patients was significantly lower than in the controls (table 3 ), as was plasma renin activity but not significantly (table 3 ). In the controls, plasma renin activity ranged from 0.12 to 3.56 $\mathrm{ng} / \mathrm{ml} / \mathrm{h}$, but one woman had a much higher value $(17.93 \mathrm{ng} / \mathrm{ml} / \mathrm{h})$. There was no apparent reason for this. After treatment for heart failure both plasma aldosterone and plasma renin activity increased significantly in the women.
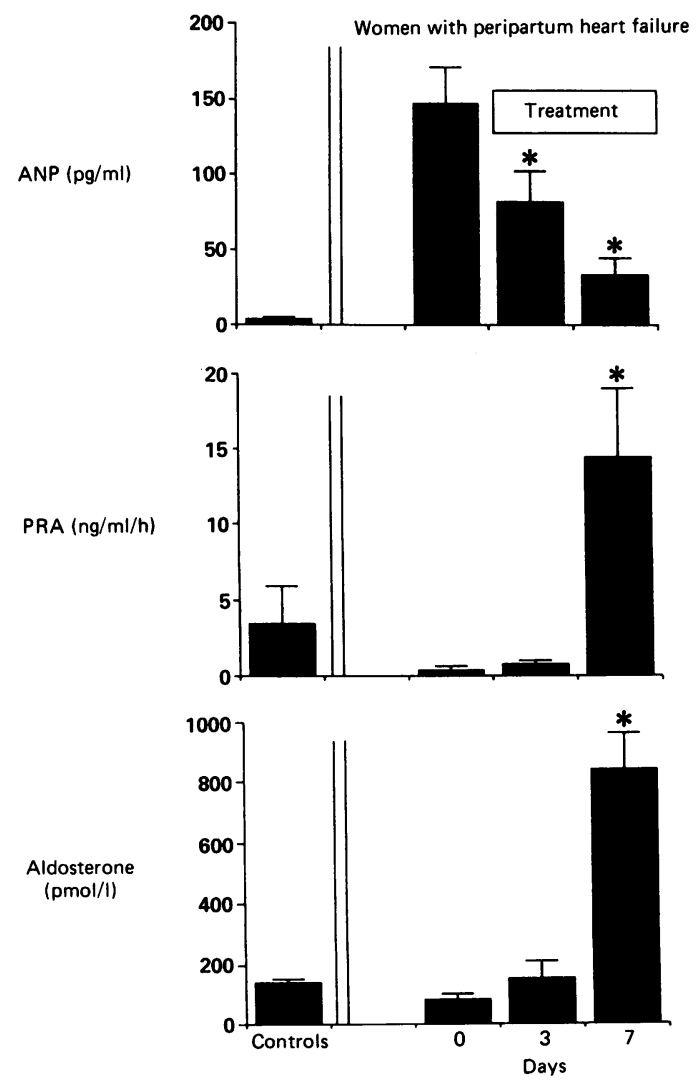

Plasma concentrations of atrial natriuretic peptide $(A N P)$, aldosterone, and plasma renin activity (PRA) in seven healthy women post partum and in seven patients with postpartum heart failure before (day 0) and after three and seven days of treatment (mean (SEM)); ${ }^{\star} p<0.05$ v basal concentrations (day 0$)$. 


\section{Discussion}

The exact cause of peripartum heart failure is yet to be identified. It occurs throughout the world, but is most common in the tropics and the tropical parts of temperate countries where hot and humid climatic conditions prevail. ${ }^{4-6}$ The high incidence in and around the northern Nigerian city of Zaria, especially during the hot and humid period of the year, has been attributed in part to the postpartum practice of salt loading and body heating in hot and humid rooms. ${ }^{2}$ Not all of the women who carry out these practices develop peripartum heart failure, however. It is possible that renal handling of salt is different in those who develop peripartum heart failure. Urinary sodium in spot samples before treatment in the patients with peripartum heart failure were significantly lower than those in the controls (table 2); this suggests sodium and water retention. This resultant salt and water Ictéiıtion could cause a high output cardiac failure. But very little is known about the associated hormonal responses. In the present study we measured plasma concentrations of atrial natriuretic peptide, aldosterone, and renin in the women who developed peripartum heart failure and those who did not have heart failure after the postpartum rituals. Previous studies have shown that plasma concentrations of atrial natriuretic peptide increased in healthy individuals during increased sodium intake ${ }^{3}$ and much increased concentrations were reported in patients with overt heart failure. ${ }^{78}$ In patients with heart failure, the high concentrations of atrial natriuretic peptide before treatment may, therefore, be a response to both the heart failure and to sodium retention; after correction of the heart failure atrial natriuretic peptide concentrations usually return towards normal. ${ }^{9}$ In the patients with peripartum heart failure in the present study atrial natriuretic peptide was considerably reduced after treatment (figure). It would have been interesting to measure atrial natriuretic peptide during salt loading and heating, but this was impracticable because at this stage patients stayed at home.

Plasma concentrations of atrial natriuretic peptide in patients were extremely high (in excess of $100 \mathrm{pg} / \mathrm{ml}$ ) before treatment but two of the seven patients had plasma concentrations of atrial natriuretic peptide below $100 \mathrm{pg} / \mathrm{ml}$. One of these (case 6: plasma atrial natriuretic peptide $59.2 \mathrm{pg} / \mathrm{ml}$ ) had heated her body but not taken an extra salt load. The intense vasodilatation caused by lying on a heated bed in a hot and humid room, and taking very hot baths twice a day for 40 days may have increased her blood volume enough to induce heart failure.

Before treatment in the patients with peripartum heart failure plasma aldosterone and plasma renin activity were within the normal range but were slightly lower than in the controls (table 3). Treatment reduced the plasma concentration of atrial natriuretic peptide and increased plasma aldosterone and plasma renin activity (figure). These changes most probably reflect the associated reduction in the extracellular fluid volume. Atrial natriuretic peptide may be one of the many factors that are important in the control of renin release. $^{8}$ Before treatment atrial natriuretic peptide may have been sufficiently raised to contribute to the observed suppression of renin and aldosterone.

In conclusion, patients with peripartum heart failure have raised concentrations of plasma atrial natriuretic peptide and suppressed concentrations of plasma aldosterone and renin. This accords with heart failure induced by hypervolaemia. The heart failure responded rapidly to treatment and the concentrations of circulating hormones were restored to normal.

We thank Mr M G Buckley, Mrs M Miller, and Dr A L Sugden for the plasma hormone measurements.

1 Davidson NMcD, Parry EHO Peripartum cardiac failure. Q J Med 1978;47:431-61

2 Sandersen JE, Adesanya CO, Anjorin FI, Parry EHO. Postpartum cardiac failure-heart failure due to volum overload? Am Heart J 1979;97:613-21.

3 Sagnella GA, Markandu ND, Shore AC, MacGregor GA Effects of changes in dietary sodium intake and salin infusion on immunoreactive atrial natriuretic peptide in human plasma. Lancet 1985;ii:1208-11.

4 Demakis JG, Rahimtoola SH, Sutton GG, et al. Natura course of peripartum cardiomyopathy. Circulation 1971, 44:1053-61.

5 Meadow WR. Postpartum heart disease. Am J Cardiol 1960;6:788-92.

6 Talabi AI, Gaba FE, George BO. Puerperal cardiomyopathy in Lagos. Tropical Cardiology 1985;11:73-8.

7 Richards AM. Human plasma atrial natriuretic peptide concentration in health and disease. Current Opin Cardiol concentration in

8 Weidmann P, Saxenhofer H, Ferrier C, Shaw SG. Atrial natriuretic peptide in man. Am J Nephrol 1988;8:1-14.

9 Anderson JV, Woodruff PWR, Bloom SR. The effect of treatment of congestive heart failure on plasma atrial natriuretic peptide concentration: a longitudinal study. $\mathrm{Br}$ Heart J 1988;59:207-11. 